\title{
A Renúncia do Papa e a História da Igreja
}

Luís Corrêa Lima

O fato inédito da renúncia de um papa, a primeira na era moderna e contemporânea, ganha luzes se vista no horizonte da história da Igreja. Até mesmo o alvoroço e a perplexidade no impacto inicial da notícia, merecem uma explicação com base na imagem e na expectativa que se tem da figura do papa, imagem que se deve às tradições que se consolidaram em torno de sua figura ao longo de séculos.

No início do pontificado de Bento XVI, um gesto simbólico seu, quase despercebido, pode ajudar a compreender o modo como ele resolveu finalizar este mesmo pontificado. Trata-se do brasão papal, um símbolo com oito séculos de história que remonta aos guerreiros e à nobreza da Idade Média. Cada papa tem seu brasão pessoal, simbolizando a sua missão.

O brasão papal costuma trazer duas chaves cruzadas sob um escudo, recordando a palavra de Cristo ao apóstolo Pedro ao lhe confiar o poder das chaves. Acima do escudo há uma tiara, uma tríplice coroa apoiada em um turbante. Quando Bento XVI anunciou o seu brasão, uma novidade: foi suprimida a tiara. Em seu lugar, há uma mitra, o chapéu de duas abas verticais utilizado pelo bispo. Esta mudança emblemática tem um significado bastante denso.

\footnotetext{
${ }^{1}$ Comunicação apresentada na mesa redonda A Renúncia do Papa e a Igreja, na PUC-Rio, em 6 de março de 2013.
} 
No passado, os papas eram coroados. Cada coroa da tiara tinha um significado. No século 16, a oração do rito de coroação se referia ao pontífice romano como "pai dos reis e chefes de Estado, detentor do supremo poder na Terra e vigário de Jesus Cristo nosso Salvador ${ }^{2 "}$. O poder temporal supremo correspondia à $2^{\mathrm{a}}$ coroa, introduzida no século 14 pelo papa Bonifácio VIII. Ele ensinava que o poder espiritual deve estabelecer e julgar o poder temporal. O segundo está subordinado ao primeiro e a serviço dele. Era a época da cristandade, em que o Estado estava ligado à Igreja, e vice-versa. Os reis e os imperadores eram coroados nas catedrais. A investidura política ocorria dentro do templo. A religião de certo modo penetrava e englobava todos os âmbitos da sociedade, exercendo uma tutela.

Tamanho poder exercido pelo papa era desconhecido no primeiro milênio. No início do cristianismo, a igreja local de Roma exercia um certo protagonismo na Igreja Católica, sendo considerada exemplo de fé e doutrina. Esta igreja particular dirimiu conflitos em outras comunidades e aprovou concílios ecumênicos. Esta autoridade, porém, não era um poder de jurisdição, uma vez que as comunidades cristãs elegiam seus próprios bispos, sem depender de comunidades vizinhas ou de Roma.

No final do primeiro milênio e início do segundo, no entanto, a Igreja no Ocidente passou por uma crise muito difícil. Reis e imperadores - que então controlavam as nomeações de bispos, abades e párocos - queriam se apropriar dos bens da Igreja e dilapidá-los em favor de nobres, generais e até bandidos com quem tinham aliança. Fizeram nomeações eclesiásticas péssimas, sem nenhum critério espiritual, levando-se muitas vezes pelo suborno (simonia). São as chamadas investiduras leigas, que chegaram a ameaçar a própria sobrevivência da Igreja.

A reação enérgica que enfrentou esta situação foi a Reforma Cluniacense, liderada por um mosteiro beneditino francês reformado que constituiu mais de mil fundações, e forneceu quadros para a renovação da vida religiosa, do clero e do papado. A solução encontrada foi uma superconcentração de poderes no papado, para enfrentar reis, imperadores e nobres ávidos de se apossar da Igreja, como aves de rapina. Em 1075, o papa Gregório VII decretou que: somente o romano pontífice pode ser chamado bispo universal, somente ele pode depor ou restabelecer bispos, somente do papa os príncipes devem beijar os pés, a ele é lícito depor o imperador, nenhuma norma e nenhum livro podem

${ }^{2}$ OLIVEIRA, M. Alves. “Tiara” In: Verbo: Enciclopédia Luso-Brasileira de Cultura, tomo 17. Lisboa: Verbo, 1975, p. 1499-1500. 
ser considerados canônicos sem a aprovação dele, a decisão dele não pode ser questionada por ninguém, somente ele pode rejeitar a sentença de qualquer um, a Igreja Romana nunca errou e, segundo o testemunho das Escrituras, nunca cairá no erro; e o papa pode liberar os súditos do juramento de fidelidade ao soberano em caso de injustiça ${ }^{3}$.

Pode-se dizer que houve uma faraonização da figura do papa. E esta superconcentração de poderes, por sua vez, uniu indissoluvelmente a pessoa do papa ao seu ofício. O corpo do papa só pode ser um corpo público, que pertence a Cristo e à Igreja, e não ao próprio papa. Na eclesiologia medieval, qualquer tentativa de dissociar a pessoa física do papa da sua função pontifícia seria rejeitada. O papa só voltaria a ser um simples homem morrendo como papa. No século 13, o bispo inglês Roberto Grosseteste afirmou em um memorial ao papa Inocêncio IV:

Aquele que preside a Sagrada Sé [Roma] se reveste da pessoa de Cristo [...] Se um deles - e que isto nunca aconteça - usa a veste de parentes ou da própria carne ou do mundo ou qualquer outro que não seja a de Cristo, então ele se separa de Cristo e de seu corpo que é a Igreja ${ }^{4}$.

Seguindo esta doutrina, o sofrimento da Igreja é o sofrimento do papa, e reciprocamente, o sofrimento do papa é o sofrimento da Igreja. Na caducidade ou na decrepitude, o corpo do papa é ainda mais assimilado pelo corpo absoluto de Cristo, certamente crucificado mas eternamente glorioso ${ }^{5}$. A possibilidade de renúncia foi prevista por Bonifácio VIII, no caso de o papa assim o manifestar, bastando uma causa grave que na sua consciência o impeça de presidir o governo da Igreja universal ${ }^{6}$.

$\mathrm{O}$ seu antecessor, Celestino V, um monge eremita feito papa, renunciou cinco meses depois de sua própria eleição, em 1294. O grande poeta Dante Alighieri não o perdoou pela renúncia. E em sua obra maior, a Divina Comédia, Celestino V habita no Inferno (Canto III, $\mathrm{n}^{\circ}$ 58-66):

[...] Eis, de repente,

Olhando, conheci a sombra daquele

Que a grã renúncia fez ignobilmente.

\footnotetext{
${ }^{3}$ Dictatus papae In: FRÖHLICH, Roland. Curso básico de história da Igreja. São Paulo: Paulinas, 1987, p. 84.

${ }^{4}$ In: ZIZOLA, Giancarlo. L'Ultimo Trono: Papa Wojtyla e il futuro dela Chiesa. Milão: Il Sole 24 ORE, 2001, 349

${ }^{5}$ Ibidem, p. 350 .

${ }^{6}$ BONIFÁCIO VII, Constituição Quoniam In: ZIZOLA, o. c., p. 355.
} 
Soube logo, o que ao certo me revele,

Que era a seita das almas aviltadas,

Que os maus odeiam e que Deus repele.

Nunca tiveram vida as desgraçadas;

Sempre, nuas estando, as torturavam

As ferroadas de vespas e mutucas.

A oposição à renúncia papal atravessa os séculos. O papa Pio XII, em meados do século 20, ao legislar sobre a sede vacante, solicita:

Pedimos ao nosso herdeiro e sucessor que não se deixe abater pelas dificuldades do cargo, afastando-se do mesmo, mas, pelo contrário, humildemente se entregue aos desígnios da vontade de Deus, porque Ele que impôs o peso será também a grande força para aquele que carrega o fardo 7 .

Este trecho foi lembrado ao secretário do papa João XXIII, na Quaresma de 1963, quando o papa já estava já bem doente e disposto a renunciar, reconhecendo-se impossibilitado de levar avante os trabalhos do Concílio Vaticano II. João XXIII não renunciou e faleceu poucos meses depois.

A extensão autoridade do papa será fortemente restringida com a emergência da modernidade e o fim da cristandade. Igreja e Estado se separam, a investidura dos governantes não ocorre mais nas catedrais, e o papa não pode mais depor os chefes de Estado. A infalibilidade papal, afirmada pelo Concílio Vaticano I, no século 19, é restrita a conteúdos referentes à Revelação divina e em circunstâncias bem especiais. O Concílio Vaticano II, por sua vez, declara que o magistério da Igreja não está acima da palavra de Deus, mas a seu serviço, ensinando apenas o que foi transmitido. Há um apelo a um protagonismo maior dos leigos na missão da Igreja, e também a uma participação maior dos bispos no governo da Igreja, a chamada colegialidade.

As mudanças trazidas pelo Concílio Vaticano II também incidem nas cerimônias papais. Um mestre das celebrações litúrgicas pontifícias relata que até o Concílio, por ocasião das grandes solenidades, o papa entrava na Basílica de São Pedro ao som de trombetas de prata, com tiara, luvas e sapatos da cor litúrgica. Era carregado na sedia gestatoria por um grupo de homens (os sediários), cercado de flabelli (portadores de leques) e de uma multidão de personagens os mais variados, leigos e prelados, cada um com a vestimenta própria de sua função, representando a nobreza, o patriciado romano,

${ }_{7}$ PIO XII, Vacantis apostolicae sedis. Roma, 1945, nº99. Disponível em: <www.vatican.va>. Acesso em: 6 mar. 2013. 
os diversos corpos de guarda e outros dignitários da corte pontifícia. Tratava-se de uma entrada solene que dava a ideia do papa como um príncipe deste mundo, cercado de sua corte. Depois do Concílio, costuma-se ver o papa participando de uma procissão de entrada na mesma Basílica, vestido como os bispos da Igreja, cercado não de pessoas da corte papal, mas pelos concelebrantes e ministros que desempenham uma função na celebração ${ }^{8}$. Houve, portanto, uma 'desfaraonização' da figura do papa.

Ao tratar da liberdade de consciência, O Concílio Vaticano II afirmou o direito de a pessoa agir segundo a norma reta da sua consciência, e o dever de não agir contra ela. Nela está o 'sacrário da pessoa', onde Deus está presente e se manifesta. Pela fidelidade à voz da consciência, os cristãos estão unidos aos outros homens no dever de buscar a verdade, e de nela resolver os problemas morais da vida individual e social ${ }^{9}$. O Catecismo da Igreja Católica incorpora e desenvolve este ensinamento conciliar, citando o bem-aventurado cardeal Newman, importante teólogo do século 19. A consciência:

É a mensageira d'Aquele que, tanto no mundo da natureza como no da graça, nos fala veladamente, nos instrui e nos governa. A consciência é o primeiro de todos os vigários de Cristo $\left(\mathrm{n}^{\circ} 1778\right)$.

Sem negar o papel do papa e também dos bispos como representantes de Cristo, quem primeiro representa Cristo para o fiel é a sua própria consciência. Inegavelmente, há uma mudança no papel do papa. Um fiel diante de Gregório VII é muito diferente de um fiel hoje diante do papa.

Outra novidade trazida pelo Concílio Vaticano II é a renúncia dos bispos, a ser apresentada quando estiverem menos aptos para exercer o seu ministério por motivo de idade avançada, ou por outra causa grave ${ }^{10}$. E Paulo VI logo fixou esta idade em 75 anos $^{11}$. Até então, os bispos não renunciavam. O papa também é bispo, bispo de Roma, e também pode estar menos apto para o seu ministério pelos mesmos motivos. Porém, a renúncia papal era mais compli-

\footnotetext{
${ }^{8}$ MARINI, Piero. "Liturgie et beauté: expériences de renouveau de certaines célébrations pontificales". La documentation catholique, n²323, 7 nov. 2004, p. 910.

${ }^{9}$ CONCÍlIO VATICAO II. Constituição pastoral Gaudium et spes sobre a Igreja no mundo actual. Roma, 1965, n¹6. Disponível em: <www.vatican.va>. Acesso em: 6 mar. 2013.

${ }^{10}$ Idem. Decreto Christus dominus sobre a função pastoral dos bispos na Igreja. Roma, 1965, n²1. Disponível em: <www.vatican.va>. Acesso em: 6 mar. 2013.

${ }^{11}$ PAULO VI. Ecclesiae sanctae: Normas para la aplicación del decretos conciliares. Roma, 1966, $\mathrm{n}^{\circ}$ I, 11. Disponível em: <www.clerus.org >. Acesso em: 6 mar. 2013.
} 
cada. Paulo VI pensou seriamente nesta hipótese, mas confidenciou: "seria um trauma para a Igreja ${ }^{12}$ ". E não teve coragem de renunciar.

Já o papa João Paulo II chegou a dizer, em 1992, que "seria belo um papa poder ver a eleição de seu sucessor ${ }^{13}$ ". No final de sua vida, entretanto, já bastante debilitado e muito distante do cargo, ele temeu criar um precedente perigoso para os seus sucessores, que poderiam ser expostos a manobras e pressões sutis, por parte de quem desejasse depô-los ${ }^{14}$. Bento XVI, por sua vez, tratou da renúncia de maneira muito objetiva e assertiva. Em 2010, ele declarou que quando um papa chega à clara consciência de já não se encontrar em condições físicas, mentais e espirituais de exercer o encargo que lhe foi confiado, então ele tem o direito - e, em algumas circunstâncias, também o dever - de renunciar ${ }^{15}$. Ratzinger cumpriu rigorosamente o que havia dito, pouco antes de completar 86 anos de idade. O mundo ficou perplexo, haja vista a enorme repercussão na mídia. Mas não há mistério. É apenas o cumprimento da palavra em tratando de algo completamente inusitado.

A fidelidade a Cristo pode ser entendida de maneiras diferentes. Para uns, é necessário que o papa permaneça na sua função até ficar decrépito, porque Cristo não desceu da cruz. Para outros, o declínio das forças justifica a renúncia, como no caso dos bispos, em favor de quem possa suceder com mais condições, para o bem da Igreja. Tudo indica que no futuro nada mais será como antes. O papa fica mais humano e menos personalista. O seu ofício pode ser visto melhor como um serviço de governo, como um pastor que passa adiante o cajado na hora adequada. Este gesto da renúncia revela uma liberdade de decisão e uma ousadia que lembram João XXIII e os inícios de Paulo $\mathrm{VI}^{16}$. Restam ainda muitos desafios aos próximos papas, entre os quais uma maior colegialidade no governo da Igreja, com mais participação e menos centralismo, que no final do último milênio cresceu.

Bento XVI iniciou o seu pontificado suprimindo a tiara do brasão ponti-

\footnotetext{
${ }^{12}$ DEZZA, Paolo (cardeal jesuíta, confessor de Paulo VI). Avvenire, 24 set. 1997 In: ZIZOLA, o. c., p. 352.

${ }^{13}$ ZIZOLA, ibidem.

${ }^{14}$ HERRANZ, Julián. Nei dintorni di Gerico In: TORNIELLI, Andrea. "Wojtyla e o 'não' à renúncia: 'Um precedente perigoso"'. La Stampa, 13 fev. 2013. Disponível em: <www.ihu. unisinos.br>. Acesso em: 6 mar. 2013.

${ }^{15}$ BENTO XVI. Luz do mundo: O papa, a Igreja e os sinais dos tempos. Uma conversa com Peter Seewald. São Paulo: Paulinas, 2011, p. 48-49.

${ }^{16}$ SUSIN, Luiz Carlos. "Quebra de paradigma”. Zero Hora 12 fev. 2013. Disponível em: <www. ihu.unisinos.br>. Acesso em: 6 mar. 2013.
} 
fício, substituindo-a pela mitra dos bispos. Agora ele finaliza este pontificado não morrendo como papa, mas renunciando como os bispos. Ele teve a coragem de mexer com coisas que não se mexiam há seiscentos anos. As tradições não devem ser fósseis intocáveis, mas sim um legado a ser assimilado com o devido discernimento, para o bem da Igreja. Oxalá esta coragem seja contagiante. Parabéns, papa Bento XVI, pelo exemplo de sabedoria, humildade e sobretudo ousadia.

Luis Corrêa Lima

Padre jesuita, historiador e professor do Departamento de Teologia da PUC-Rio.

E-mail:1clima@puc-rio.br

Recebido em: 01/04/13

Aprovado em: 15/04/13 